\title{
Individual and Synergistic Effects of Rabbit Granulocyte Proteins on Escherichia coli
}

\author{
Ofer Levy, ${ }^{*}$ Chean Eng Ooi, ${ }^{*}$ Jerrold Weiss, ${ }^{*}$ Robert I. Lehrer, ${ }^{\ddagger}$ and Peter Elsbach* \\ $*$ Departments of Microbiology and Medicine, New York University School of Medicine, New York 10016; and ${ }^{\ddagger}$ Department of Medicine, \\ University of California, Los Angeles, School of Medicine, Los Angeles, California 90024
}

\begin{abstract}
Affinity purification of crude acid extracts of rabbit polymorphonuclear leukocytes using Escherichia coli (J5) as adsorbent yields the bactericidal/permeability-increasing protein (BPI), two 15-kD species (p15s), and the two most potent (cationic) defensin species (neutrophil peptides [NP] -1 and $-2)$. Tested in buffered isotonic medium, the relative antibacterial potency of these proteins against $E$. coli $\mathrm{J} 5$ is BPI $\left(\right.$ IC $\left._{50} 0.2 \mathrm{nM}\right)>$ p15A $(10 \mathrm{nM})>\mathrm{NP}-1$ (400 nM). Sublethal doses of p15A or NP-1 can synergize with BPI to decrease the dose required to inhibit the growth of $E$. coli by up to 50-fold. BPI and p15A display similar features of antibacterial action distinct from defensin NP-1, but NP-1 acts synergistically only with BPI and not with p15A. All aspects of the combined action of BPI and NP-1 resemble those observed with higher concentrations of BPI alone, implying that NP-1 enhances BPI potency. Neither NP-1 nor p15A alter the amount of BPI binding to $E$. coli but BPI enhances binding of p15A to $E$. coli, raising the possibility that synergy between these two proteins may occur at least partially at the level of binding. The potent synergistic actions of these proteins can also be demonstrated against serum-resistant clinical isolates of encapsulated $E$. coli tested in whole blood and plasma ex vivo, suggesting that such combined action may contribute to host defense in vivo. (J. Clin. Invest. 1994. 94:672-682.) Key words: neutrophils - Gram-negative bacteria • defense mechanisms • combined antibiotics. blood
\end{abstract}

\section{Introduction}

The PMN, a central element in host-defense against bacterial infection, is equipped with an extensive antimicrobial arsenal

Ofer Levy and Chean Eng Ooi contributed equally to this work.

A preliminary report of this work was presented at the national meeting of the American Society for Clinical Investigation in Washington, DC on 30 April to 3 May 1993. Portions of this work were published in abstract form (1993. Clin. Res. 41:247a).

Address correspondence to Dr. Jerrold Weiss, Department of Microbiology, NYU School of Medicine, 550 First Avenue, New York, NY 10016.

Received for publication 10 September 1993 and in revised form 5 April 1994.

J. Clin. Invest.

(C) The American Society for Clinical Investigation, Inc.

0021-9738/94/08/0672/11 $\$ 2.00$

Volume 94, August 1994, 672-682 that consists of both oxygen-derived and nonoxidative toxic agents $(1,2)$. Remarkable progress has been made in the identification and characterization of individual elements of both systems (3-7). By taking advantage of the availability of these proteins and peptides in pure form, obtained either by traditional purification or by recombinant DNA methods, their antimicrobial actions as individual agents have been analyzed extensively in vitro $(2,3)$. Consequently, much has been learned about the structures and biological properties of cationic antimicrobial PMN proteins and peptides such as the $50-\mathrm{kD}$ bactericidal/ permeability-increasing protein $(\mathrm{BPI})^{1}(8,9)$ and the $3-4-\mathrm{kD}$ defensins (10). We have proposed that BPI plays a primary antibacterial role toward Gram-negative bacteria in the intact PMN because of the very close similarity of the fate of BPIsensitive bacteria ingested by intact PMN or exposed to purified BPI $(11,12)$. We recognize, however, that the coexistence in the PMN of many distinct antimicrobial entities leaves uncertain the actual contribution of individual elements to overall PMN function. We therefore initiated the present study, guided by what we have learned before from the interaction of the Gramnegative bacterium Escherichia coli with two granule-associated protein species of PMN, BPI (13), and the 15-kD proteins (p15s) $(14,15)$. We have examined the antimicrobial effect of these well-defined proteins as well as of members of the defensin family, alone and in combination. The results indicate not only qualitative and quantitative differences in the direct actions of these proteins on $E$. coli but also that the antimicrobial potency of a mix of BPI and p15s or defensins in artificial media as well as in whole blood is far greater than of each alone, revealing a previously unrecognized synergy between these components of the antimicrobial systems of the PMN.

\section{Methods}

Bacteria. Bacteria used in this study included E. coli J5, a "rough" UDP-4-galactose-epimerase-less mutant of the smooth strain 0111:B4, two K1-encapsulated strains of $E$. coli (the rough LPS chemotype " $\mathrm{K} 1 /$ $r$ " and the smooth LPS chemotype "018K1") kindly provided by Dr. Alan Cross (Department of Bacterial Diseases, Walter Reed Army Medical Center, Washington, DC) that were part of a collection of bacteremic isolates previously characterized by phage typing for $\mathrm{K} 1$ capsule (16), and Staphylococcus aureus (Cowan strain) obtained from the New York University Medical School Department of Microbiology bacteria collection. Bacteria were maintained either on nutrient broth/agar slants at

1. Abbreviations used in this paper: BPI, bactericidal/permeability-increasing protein; NP, rabbit neutrophil peptide (defensin); p15s, 15-kD proteins of rabbit granulocytes; TBS, Tris/HCl-buffered saline. 
$4^{\circ} \mathrm{C}$ or as log phase subcultures grown in Luria Broth and stored in $10 \%$ glycerol at $-80^{\circ} \mathrm{C}$. Bacteria were grown either in $0.8 \%(\mathrm{wt} / \mathrm{vol})$ nutrient broth (Difco Laboratories Inc., Detroit, MI) in saline $(E$. coli J5) or in 3\% trypticase soy broth (Becton Dickinson and Co., Cockeysville, $\mathrm{MD}$ ) in water $(E$. coli $\mathrm{K} 1 / \mathrm{r}$ and $E$. coli $018 \mathrm{~K} 1)$. Stationary phase overnight cultures were transferred to fresh medium (diluted 1:50 or 1:100) and grown to $\log$ phase $(2.5 \mathrm{~h} \mathrm{~J} 5,4 \mathrm{~h}$ encapsulated strains) at $37^{\circ} \mathrm{C}$. Bacterial concentrations were determined by measuring the $\mathrm{OD}_{550}$ in a spectrophotometer (Junior model; Coleman Instruments, Inc., Maywood, IL). Subcultures were harvested by sedimentation of bacteria at 3,000 $\mathrm{g}$ for $10 \mathrm{~min}$. Bacteria were resuspended in physiological saline to the desired concentration. For determining the effect of saline on antibacterial activity, bacteria were resuspended either in $10 \mathrm{mM}$ sodium phosphate buffer, $\mathrm{pH} 7.4$, or in the same buffer containing physiological (0.9\%) saline.

Proteins. BPI, p15s, and defensins NP-1 and -2 were isolated from the peritoneal exudate PMN of New Zealand White rabbits using a modification of the affinity purification procedure described by Mannion et al. (13). Briefly, rabbit leukocytes ( $>90 \%$ granulocytes) were obtained from overnight glycogen-induced peritoneal exudates, pelleted by centrifugation, and stored at $-20^{\circ} \mathrm{C}$ before homogenization in distilled water and extraction with $0.16 \mathrm{~N}$ sulfuric acid at $4^{\circ} \mathrm{C}$. After neutralization by dialysis against $1 \mathrm{mM}$ Tris/ $\mathrm{HCl}, \mathrm{pH} 7.5$, for $4 \mathrm{~d}$ with three changes of dialysis buffer per day and removal of precipitates by centrifugation for $20 \mathrm{~min}$ at $23,000 \mathrm{~g}$, the supernatant, referred to as "crude extract" was recovered. PMN crude extract was incubated with $E$. coli J5 $\left(5 \times 10^{8} / \mathrm{ml}\right)$ for $15 \mathrm{~min}$ at $37^{\circ} \mathrm{C}$ in $20 \mathrm{mM}$ sodium acetate buffer, $\mathrm{pH}$ 4.0. After centrifugation at $3,000 \mathrm{~g}$ for $10 \mathrm{~min}$ to remove unbound material, the bacterial pellets were washed twice with half volumes of the incubation medium. Bound proteins were eluted from $E$. coli suspensions $\left(5 \times 10^{9} / \mathrm{ml}\right)$ during incubation in $200 \mathrm{mM} \mathrm{MgCl}_{2}$ buffered with $20 \mathrm{mM}$ acetate, at $\mathrm{pH} 4$, for $15 \mathrm{~min}$ at $37^{\circ} \mathrm{C}$. After removal of the bacteria by centrifugation, the supernatant was dialyzed against $20 \mathrm{mM}$ sodium acetate buffer, $\mathrm{pH} 4.0$, and referred to as the "magnesium eluate." To increase yields of the defensin peptides, the initial unbound material was incubated with a fresh batch of $E$. coli generating an additional magnesium eluate. Magnesium eluates were subjected to reverse-phase HPLC on a C4 column (Vydac, Hesperia, CA) using a 30min linear gradient of 0-95\% acetonitrile (J.T. Baker, Inc., Phillipsburg, $\mathrm{NJ}$ ) in $0.1 \%$ (vol/vol) trifluoroacetic acid (Pierce Chemical Co., Rockford, IL), as described previously (14). Eluted proteins were promptly dialyzed versus $20 \mathrm{mM}$ sodium acetate buffer, $\mathrm{pH}$ 4.0. To separate p15 isoforms A and B, the p15-rich fraction from initial HPLC was applied again with a $0-67 \%$ gradient developed over $60 \mathrm{~min}$. BPI and p15s were identified by their characteristic migrations (HPLC and SDS-PAGE), immunoreactivities, and bioactivities. p15A and p15B refer to the two chromatographically and functionally distinct isoforms isolated from a single rabbit (15). The two peptides isolated were subjected to amino acid analysis as described previously (17) as well as amino-terminal amino acid sequencing by sequential Edman degradation on a gas phase sequencer (model 475A; Applied Biosystems, Inc., Foster City, CA). The presence in the crude acid extract of the five rabbit defensin isoforms (NP-1-5) was determined by acid-urea PAGE as described previously (18). Defensins NP-1, -2, and -5 were also isolated from citric acid extracts of rabbit PMN as described previously (19).

Growth inhibitory assays in artificial media. To evaluate the effect of physiologic saline on the growth inhibitory activity of granulocyte proteins, E. coli $\mathrm{J} 5\left(10^{6} / \mathrm{ml}\right)$ in sodium phosphate buffer, $\mathrm{pH} 7.4$, with or without saline $(0.9 \% \mathrm{wt} / \mathrm{vol})$ were incubated with granulocyte proteins (or acetate buffer alone). For measurement of synergistic actions, incubation mixtures of $1-4 \times 10^{7}$ bacteria/ml contained $0.8 \%(\mathrm{wt} / \mathrm{vol})$ nutrient broth in saline buffered with $20 \mathrm{mM}$ sodium phosphate, $\mathrm{pH} 6.0$ (7.4 for those assays done in parallel with phospholipid hydrolysis). Bacteria were incubated with proteins for $15 \mathrm{~min}$ at $37^{\circ} \mathrm{C}$ before measurement of viability.

Activation of phospholipolysis. Hydrolysis of bacterial phospholipids was measured as release of radiolabel from bacteria that had been prela- beled during growth with $1 \mu \mathrm{Ci} / \mathrm{ml}$ of $\left[1-{ }^{14} \mathrm{C}\right]$ oleic acid (Du Pont/New England Nuclear, Boston, MA). Incubation mixtures consisted of $4 \times$ $10^{7}$ bacteria/ml in $0.8 \%(\mathrm{wt} / \mathrm{vol})$ nutrient broth in saline buffered, at $\mathrm{pH}$ 7.4 , with $20 \mathrm{mM}$ sodium phosphate and supplemented with $0.25 \%$ BSA to capture labeled phospholipid breakdown products. After incubation for $30 \mathrm{~min}$, incubation mixtures were spun in a centrifuge (Eppendorf North America, Inc., Madison, WI) at 14,000 rpm for 3 min to separate unhydrolyzed phospholipids retained in the pellet and breakdown products complexed to albumin in the supernatant. Hydrolysis was quantitated by counting radioactivity in the supernatant in an LS 5000 TD (Beckman Instruments, Inc., Fullerton, CA) and was expressed as percent of the total radioactivity present in the incubation mixture.

Binding assays. For measurement of binding, purified proteins were incubated with $\left[1-{ }^{14} \mathrm{C}\right]$ oleic acid-labeled $E$. coli $\mathrm{J} 5\left(4 \times 10^{7} /\right.$

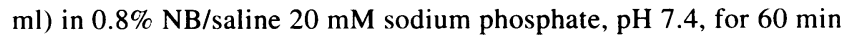
at $37^{\circ} \mathrm{C}$. After removing an aliquot for measurement of bacterial viability, the remaining suspension was centrifuged (Eppendorf microfuge $14 \times 10^{3} \mathrm{rpm}, 5 \mathrm{~min}$, room temperature), the supernatant was analyzed for products of phospholipid hydrolysis as described above, and the bacterial pellet was washed twice with one-half sample volumes of saline buffered with $20 \mathrm{mM}$ sodium phosphate, $\mathrm{pH}$ 7.4. The bacterial pellets were then transferred to fresh tubes with three washes of $25 \mu \mathrm{l}$ distilled water, lyophilized using a Savant Speed Vac (Farmingdale, NY), and stored at $-20^{\circ} \mathrm{C}$ until further analysis of protein binding by immunoblotting.

Western blotting. Bacterial pellets were solubilized in $20-40 \mu 12 \times$ SDS-PAGE buffer (20) and analyzed on 14\% (p15) and 12\% (BPI) polyacrylamide gels. Western transfer was performed at $200 \mathrm{~mA}$ for 16 $\mathrm{h}$ in a Bio-Rad (Cambridge, MA) apparatus as described (21). Nitrocellulose blots were blocked for $1 \mathrm{~h}$ at $37^{\circ} \mathrm{C}$ with $0.3 \% \mathrm{BSA} / 10 \mathrm{mM}$ Tris/ HCl-buffered saline (TBS, pH 7.4)/0.1\% sodium azide, washed with TBS for $5 \mathrm{~min}$, and then exposed to either $0.3 \%$ ( $\mathrm{vol} / \mathrm{vol}$ ) guinea pig anti-p15 serum or $0.1 \%(\mathrm{vol} / \mathrm{vol})$ goat anti-BPI serum in incubation buffer (0.3\% BSA/TBS/0.1\% sodium azide/0.5\% NP-40/5 mM EDTA, $\mathrm{pH} 8.0$ ) at room temperature, shaking for $3 \mathrm{~h}$. The blots were washed six times with TBS and once with incubation buffer ( 5 min each), and bound antibody was detected by incubation for $3 \mathrm{~h}$ in incubation buffer supplemented with $0.2 \%$ (vol/vol) ${ }^{125} \mathrm{I}$-protein G (DuPont/New England Nuclear). After six 5-min washes with TBS, blots were air dried and exposed for autoradiography on Kodak XAR film. Autoradiograms were scanned under uniform settings of contrast and brightness with a ScanJet Plus scanner (Hewlett-Packard Co., Palo Alto, CA) using the DeskScan program (version 2.1; Hewlett-Packard Co.), edited using NIH Image (version 1.52; courtesy of Wayne Rasband, National Institutes of Health) and imported to PowerPoint (version 3.0; Microsoft Co., Redmond, WA) before photography using Kodak ColorEase film.

Blood. Blood was collected from healthy human volunteers after informed consent into sterile tubes containing citrate as an anticoagulant (Becton Dickinson, Mountain View, CA). Blood samples contained 50 $\mu \mathrm{l}$ of citrated blood, $3 \mu \mathrm{l}$ of proteins in acetate buffer (or buffer alone) and $1 \mu \mathrm{l}$ of bacteria (final concentration of $10^{4} / \mathrm{ml}$ ) diluted in sterile physiological saline and added last. Samples were incubated at $37^{\circ} \mathrm{C}$ for $1 \mathrm{~h}$ before measurement of bacterial viability. For determination of antibacterial activities in the absence of cellular elements, plasma was separated from blood cells by centrifugation (Savant, 5,000 rpm, $5 \mathrm{~min}$ ) of citrated blood and recovered in the supernatant.

Measurement of bacterial viability. After the indicated incubations at $37^{\circ} \mathrm{C}$, aliquots were taken and diluted in sterile physiological saline (or

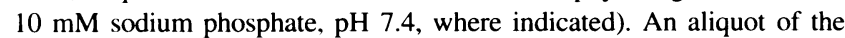
diluted sample was transferred to $5 \mathrm{ml}$ of $1.3 \%$ (wt/vol) molten $\left(48^{\circ} \mathrm{C}\right.$ ) Bactoagar (Difco Laboratories Inc.) containing $0.8 \%$ (wt/vol) nutrient broth and $0.5 \%(\mathrm{wt} / \mathrm{vol}) \mathrm{NaCl}$ and poured into a petri dish. Where indicated, the molten agar was supplemented with $1 \mathrm{mg} / \mathrm{ml}$ BSA (United States Biochemical Corp., Cleveland, $\mathrm{OH}$ ). The agar was allowed to solidify at room temperature, and bacterial viability was measured as the number of colonies formed after incubation at $37^{\circ} \mathrm{C}$ for $18-24 \mathrm{~h}$. 


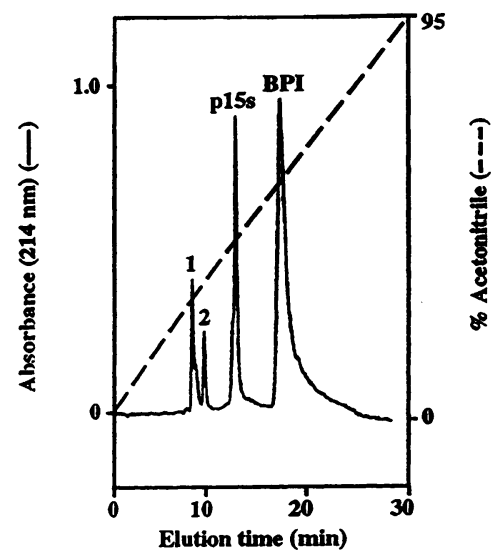

Figure 1. Purification of granulocyte proteins that bind to $E$. coli $\mathrm{J} 5$ by reverse-phase HPLC. Chromatography of the magnesium eluate was carried out as described in Methods. A linear gradient of $0-95 \%$ acetonitrile was developed in 30 $\min$ at a flow rate of 1 $\mathrm{ml} / \mathrm{min}$. Broken lines indicate the acetonitrile gradient, and solid lines represent absorbance at $214 \mathrm{~nm}$ of eluting material. $3 \mathrm{ml}$ of magnesium eluate was applied. BPI and p15s were identified by their characteristic migrations on HPLC and SDS-PAGE as well as by biological and immunological assays, while peaks 1 and 2 were identified as defensins NP-1 and NP-2, respectively, by complete $\mathrm{NH}_{2-}$ terminal amino acid sequencing.

\section{Results}

Comparison of bacterial growth inhibition by rabbit granulocyte proteins that bind preferentially to E. coli J5

In earlier studies, we analyzed the structural and antibacterial properties of proteins in crude acid extracts of PMN that preferentially bind to $E$. coli $\mathbf{J} 5$. Elution of the bound material with $200 \mathrm{mM} \mathrm{MgCl}$ yielded two major protein species that were identified as BPI (13) and the p15 isoforms (14). These proteins could then be isolated in pure form by HPLC (14). On occasion, two additional small peaks were observed in the eluate (Fig. 1, peaks 1 and 2). Upon repeating this "affinity purification" using the unbound fraction, the yield of these latter protein species was selectively increased (not shown), suggesting that they also bind preferentially to $E$. coli $\mathrm{J} 5$, but with lower affinity relative to BPI and p15s. Amino acid analysis and complete amino-terminal sequencing (not shown) revealed that the proteins in peaks 1 and 2 were the previously described antimicrobial defensins NP-1 and NP2 , respectively $(19,22)$. The less potent (and less cationic) defensins NP-3, -4 , and -5 are also present in the crude extract as judged by acid-urea PAGE (not shown) but were not recovered by this affinity purification procedure.

The ability of BPI, p15s, and defensins NP-1 and -2 to compete effectively with other PMN proteins for binding to $E$. coli is consistent with their postulated role in antibacterial host defense. Whereas BPI and defensins have been shown to inhibit growth of $E$. coli in vitro, the p15s were reported to be inactive in this respect (14). However, the assay conditions under which p15s were tested are also unfavorable for defensin action (presence of physiologic saline, $\mathrm{pH}<7.4$, as well as a relatively high bacterial concentration of $4 \times 10^{7} / \mathrm{ml} ; 19$ ). We compared the antibacterial potency of BPI, p15s, and defensins against $E$. coli J5 under the incubation conditions that were found by Selsted et al. (19) to be optimal for expression of the antibacterial action of NP-1 and NP-2 (10 mM sodium phosphate, $\mathrm{pH}$ $7.4,10^{6}$ bacteria/ml). Under these conditions (not shown), we detected for the first time direct antibacterial action of p15s.
Because these proteins are likely to exist in environments with salt concentrations in the $150 \mathrm{mM}$ range, known to reduce the potency of defensin action (18), we compared the activities of these proteins in the same medium supplemented with isotonic $(0.9 \% \mathrm{wt} / \mathrm{vol})$ sodium chloride.

The three protein species differed markedly in their antibacterial potency (Fig. 2). BPI was most potent, with an $\mathrm{IC}_{50}$ of $0.2 \mathrm{nM}$. Under these conditions, the p15s also inhibited growth of $E$. coli $\mathrm{J} 5$ in a dose-dependent manner. p15A (10 nM) was more potent than $\mathrm{p} 15 \mathrm{~B}(400 \mathrm{nM})$ which was equivalent in potency to NP-1 and NP-2 (not shown). Comparison of potencies in the absence (not shown) and presence of saline revealed that the potency of BPI was unaffected by the addition of saline, the potency of p15A decreased 5-10-fold, while that of defensin NP-1 fell 50-100-fold, confirming previous observations of its sensitivity to sodium chloride (19). Subsequent experiments were conducted with isoforms p15A and NP-1.

Defensin NP-1, like p15A, acts synergistically with BPI to inhibit growth of E. coli J5

We have demonstrated previously that at nonlethal doses the p15s (especially p15A) markedly potentiate the growth inhibitory action of BPI (14; Fig. $3 A$ ). Under the same experimental conditions $\left(4 \times 10^{7}\right.$ bacteria $/ \mathrm{ml}, 0.8 \%$ nutrient broth/saline, $\mathrm{pH}$ 6), sublethal doses of defensin NP-1 also greatly reduce the dose of BPI required for growth inhibition of $E$. coli J5 (Fig. 3 $B)$. Maximal synergistic effects were observed at $2 \mu \mathrm{M}$ NP-1 or $300 \mathrm{nM}$ p15A. Under these conditions, the IC 90 of BPI was 1-2 nM, i.e., a reduction of about 25 -fold in the BPI dose required to inhibit bacterial growth. That these interactions are truely synergistic (rather than additive) can be judged by isobolic analysis (23) with respect to the $\mathrm{IC}_{50} \mathrm{~s}$ of BPI and p15A (Fig. $3 C$ ) or NP-1 (Fig. $3 \mathrm{D}$ ) alone and in combination. NP-1 and NP-2 showed similar synergistic activity with BPI, whereas NP-5 was much less active (not shown). Similar degrees of

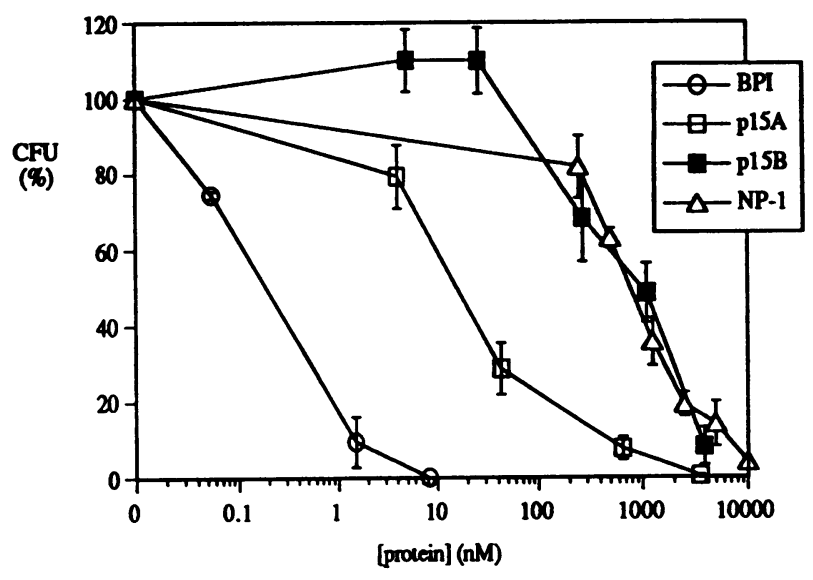

Figure 2. Bacterial growth inhibitory activities of purified granulocyte proteins in isotonic media. $E$. coli $\mathrm{J} 5\left(10^{6} / \mathrm{ml}\right)$ were incubated for $15 \mathrm{~min}$ at $37^{\circ} \mathrm{C}$ with increasing concentrations of the indicated proteins in $10 \mathrm{mM}$ sodium phosphate, $\mathrm{pH} 7.4$, in physiological saline. Viability was measured as described in Methods and is expressed as a percentage of control CFU \pm SEM of at least three independent determinations. 

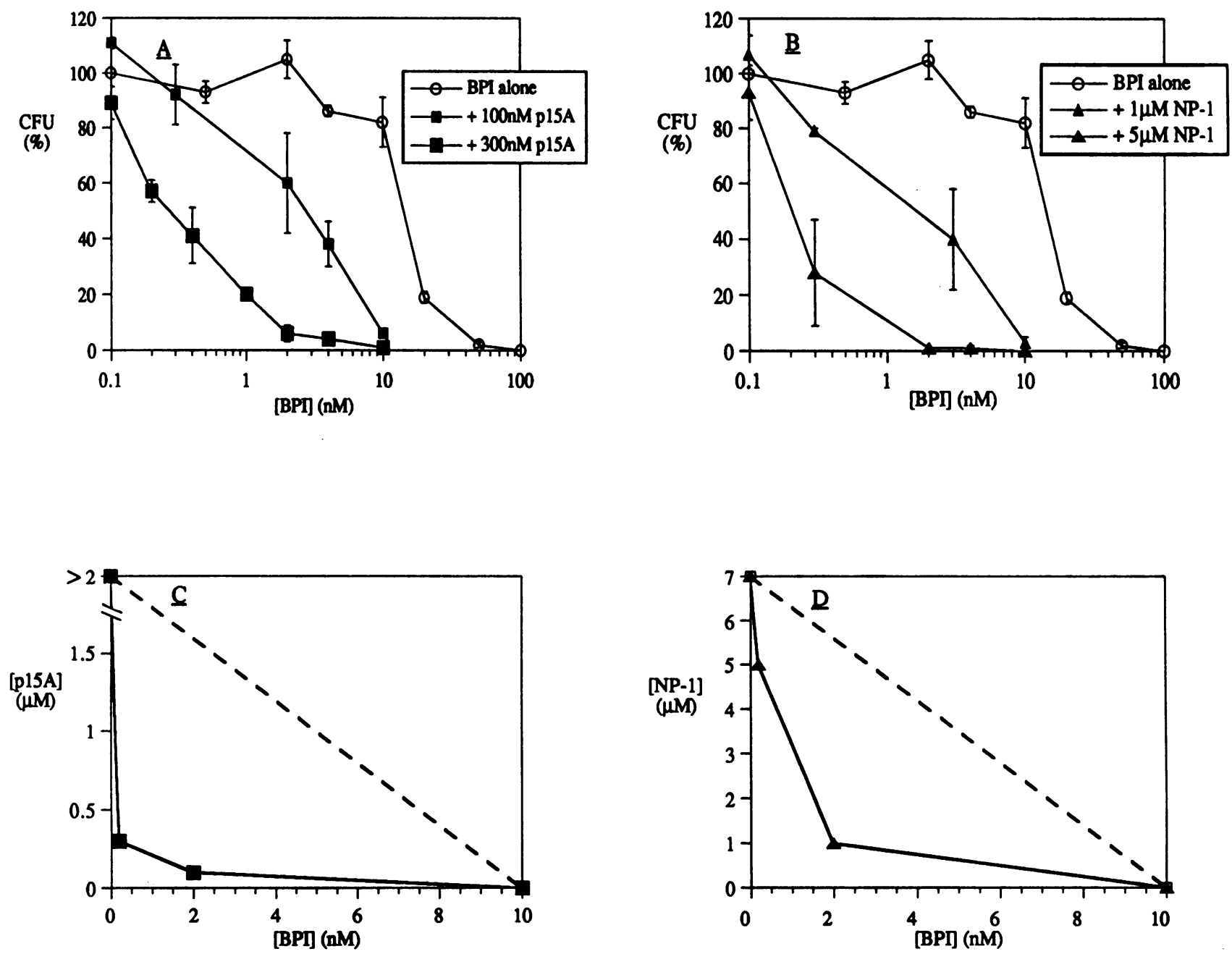

Figure 3. Synergistic effects of p15A or NP-1 with BPI on viability of $E$. coli. E. coli $\mathrm{J} 5\left(4 \times 10^{7} / \mathrm{ml}\right)$ were incubated in $0.8 \% \mathrm{NB} / \mathrm{saline}$ buffered with $20 \mathrm{mM}$ sodium phosphate, $\mathrm{pH} 6$, at $37^{\circ} \mathrm{C}$ for $15 \mathrm{~min}$ with increasing concentrations of BPI alone or in the presence of the indicated concentrations of p15A $(A)$ or NP-1 $(B)$. Results represent the mean \pm SEM of two to seven determinations. Isobolic (iso-effect) analysis with respect to the $\mathrm{IC}_{50} \mathrm{~S}$ of BPI and p15A ( $C$, solid line $)$ alone and in combination or BPI and NP-1 $(D$, solid line $)$ alone and in combination indicates that the combined effects are greater than additive (dotted line) and thus are truely synergistic.

synergy were also seen at lower bacterial concentrations and at pH 7.4 (not shown).

Little or no antibacterial activity was detected in the absence of BPI, even in the presence of micromolar doses of both p15A and NP-1 (Fig. $4 A$ ). At a low BPI dose ( $~ 2 \mathrm{nM})$, the concentration of either p15A or NP-1 required to achieve almost complete bacterial growth inhibition was reduced by the simultaneous presence of the other protein (note the combined effect of 400 nM p15A and 1.3 $\mu \mathrm{M}$ NP-1 in Fig. $4 B$ ), suggesting that the effects of NP-1 and p15A are additive and that under certain conditions all three proteins can collaboratively contribute to the fate of $E$. coli. Under the same experimental conditions, no synergistic effects against Staphylococcus aureus were detected (not shown).

Further comparison of the antibacterial effects of BPI, p15A, and NP-1 alone and in combination

Effect on growth. The synergistic action of BPI with p15A or NP-1 implies that these proteins have distinct modes of action or act in a cooperative fashion. To test the former hypothesis, we directly compared the action of the three proteins on $E$. coli. We have shown before that the early inhibition by BPI of bacterial growth can be reversed by supplementing the growth medium with albumin (11). E. coli growth-inhibited by p15A alone (Fig. $5 \mathrm{~B}$ ) or in combination with BPI (14) can also be reversed by albumin. In contrast, growth inhibition by high concentrations of NP-1 ( $\geq 10 \mu \mathrm{M})$ under these assay conditions is not reversed by albumin (Fig. $5 C$ ). However, E. coli exposed to both BPI and NP-1, like BPI-treated bacteria, could resume growth in albumin-supplemented medium (Fig. $5 \mathrm{D}$ ), suggesting that the synergism of BPI and NP-1 reflects the potentiation of BPI action by NP-1.

Effect on bacterial phospholipolysis. Another hallmark of BPI action is the activation of bacterial phospholipolysis (24). Exposure of $E$. coli $\mathrm{J} 5$ to $\geq 20 \mathrm{nM}$ BPI or $\geq 5 \mu \mathrm{M}$ p15A in buffered nutrient broth/physiological saline activates bacterial envelope phospholipid hydrolysis, whereas even $60 \mu \mathrm{M}$ NP-1 had no effect (Fig. 6). Addition of $3 \mu \mathrm{M} \mathrm{NP}-1$ (or $1 \mu \mathrm{M}$ p15A), 

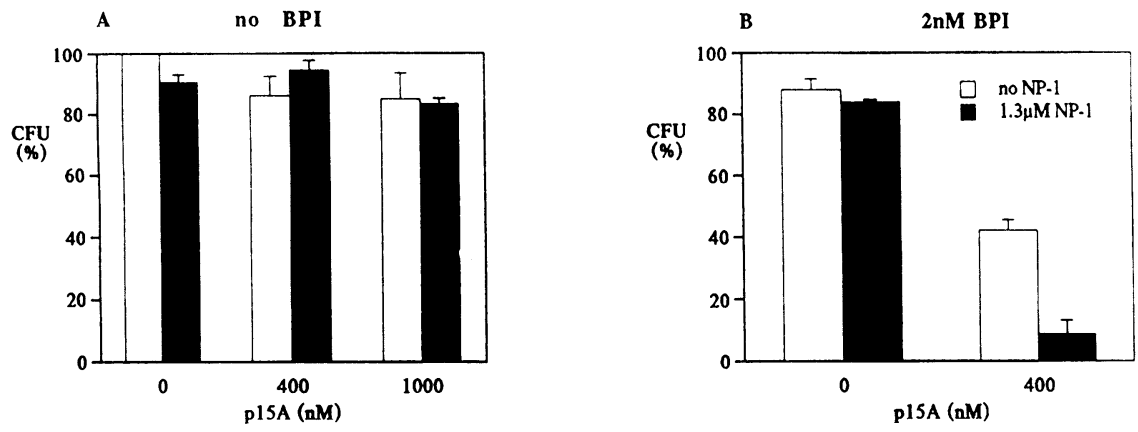

Figure 4. BPI-dependent synergistic action of granulocyte proteins. E. coli J5 were incubated (same conditions as in Fig. 3) with increasing concentrations of $\mathrm{p} 15 \mathrm{~A} \pm 1.3 \mu \mathrm{M}$ NP- 1 in the absence $(A)$ or presence $(B)$ of $2 \mathrm{nM}$ BPI. The results represent the mean \pm SEM of at least two independent determinations.

however, greatly increased the amount of phospholipolysis triggered when low doses of BPI $(<50 \mathrm{nM})$ were added, again suggesting that NP-1 was potentiating BPI action. However, because of the qualitative similarity of p15 and BPI action on
$E$. coli by the criteria used, it was not clear whether p15A was promoting BPI action or vice versa.

Bacterial binding of granulocyte proteins. To further compare the antibacterial actions of BPI and p15A and to

\section{A BPI alone}

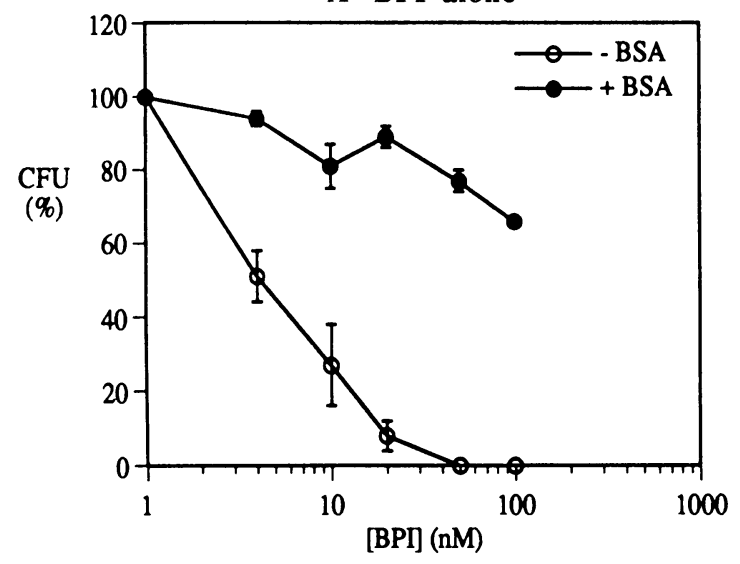

C NP-1 alone

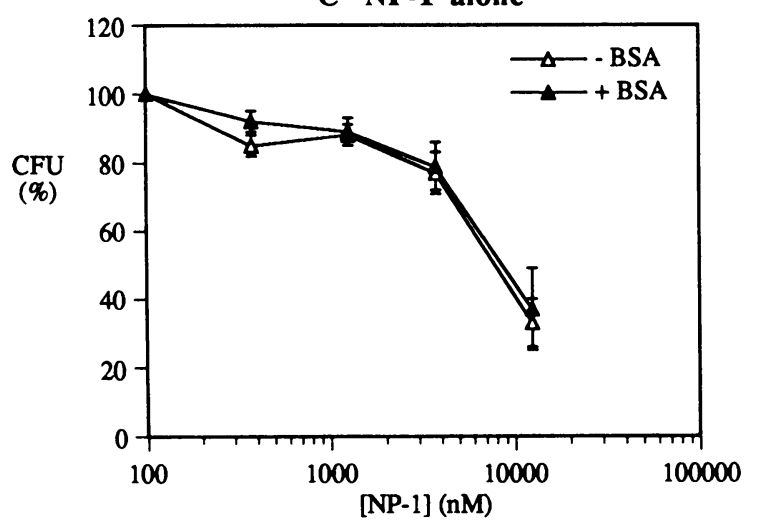

B p15A alone

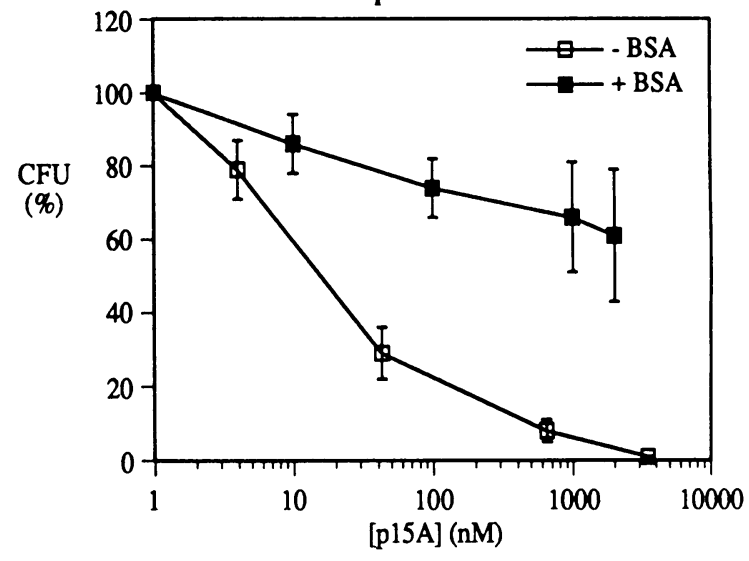

D BPI $+4 \mu \mathrm{M}$ NP-1

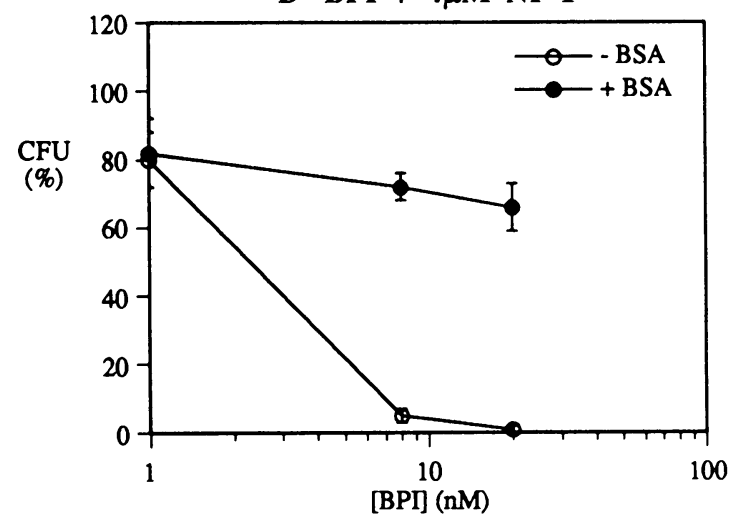

Figure 5. Ability of albumin to rescue $E$. coli growth-inhibited by BPI and/or NP-1 or p15A. Bacteria were treated with BPI $(A)$, p15 $(B)$, NP-1 $(C)$, or BPI $+4 \mu \mathrm{M} \mathrm{NP}-1(D)$. E. coli $\mathrm{J} 5$ were incubated (as in Fig. 3 for panels $5, A$. $C$. and $D$ or as in Fig. 2 for panel $5 B$ ) with increasing concentrations of proteins after which viability was determined by plating in molten agar either with (dark symbols) or without (open symbols) 1 $\mathrm{mg} / \mathrm{ml} \mathrm{BSA}$. The results represent the mean \pm SEM of three to six determinations. 


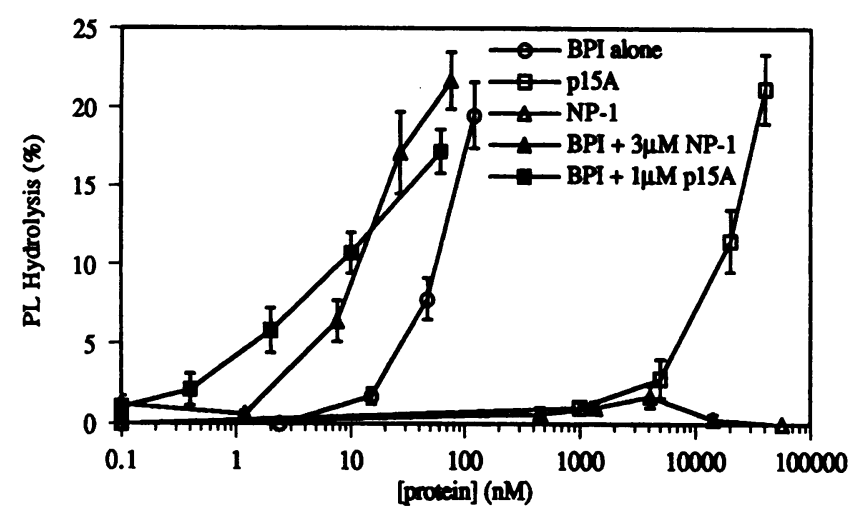

Figure 6. Activation of bacterial phospholipid hydrolysis by BPI and/ or p15A or NP-1. E. coli $\mathrm{J} 5\left(1-4 \times 10^{7} / \mathrm{ml}\right)$ prelabeled with $\left[{ }^{14} \mathrm{C}\right]$ oleic acid were incubated, at $\mathrm{pH} 7.4$, with increasing concentrations of the indicated proteins under the assay conditions described in Fig. 3. Bacterial phospholipolysis was measured as described in Methods and is presented as the percentage of total labeled phospholipid (mean \pm SEM of two to eight determinations).

explore determinants of synergy, we measured binding of BPI and p15A to E. coli by Western blot analysis (Fig. 7) in parallel with assays of bioactivity (Fig. 8). As expected because of the different affinities of the two proteins in the affinity purification (14), at nanomolar doses of either protein added alone, binding of BPI exceeded that of p15A. However, the differences in BPI and p15A binding were much less than their differences in potency (compare Fig. 8, $A$ and $B$ versus $C$ ). Thus, at doses of BPI and p15A producing similar antibacterial effects, $\sim 10$-fold more p15A was bound than BPI
(Fig. 8). Hence, BPI and p15A differ not only in their affinity for $E$. coli $\mathrm{J} 5$ but also in the potency of the proteins once bound to these target bacteria.

Within the dose range of BPI $(2-50 \mathrm{nM})$ in which synergy with p15A (or NP-1) was most pronounced, the amount of added BPI bound (from 10 to $30 \%$ ) was the same whether or not p15A or NP-1 was added (Fig. $7 A$ ). Thus, the increased antibacterial activity in the presence of p15A or NP-1 was not accompanied by increased BPI binding. In contrast, BPI stimulated in a dose-dependent manner binding of p15A (Figs. $7 B$ and $8 \mathrm{C}$ ).

\section{Independent and synergistic antibacterial action of BPI, p15, and NP-1 in whole blood ex vivo}

To determine if the independent and combined actions of rabbit BPI, p15A, and NP-1 against $E$. coli are also manifest in more complex, physiological environments, we examined the action of these proteins either alone or together in whole blood against two strains of K1-encapsulated $E$. coli that resist the cellular and extracellular antibacterial systems present in normal blood. As shown previously with human BPI (25), in whole blood rabbit BPI potently inhibited viability of $E$. coli $\mathrm{K} 1 / \mathrm{r}$ (Fig. 9 $A$ ), an encapsulated strain producing short chain (R-chemotype) LPS that is about as sensitive as $E$. coli J5 to BPI in simple buffered isotonic media (not shown). Added p15A or NP-1 also caused killing of $E$. coli $\mathrm{K} 1 / \mathrm{r}$ in whole blood ex vivo (Fig. 9 $A$ ) but required three to four orders of magnitude higher molar concentrations than that required for BPI (IC $902 \mathrm{nM}, 2 \mu \mathrm{M}$, and $10 \mu \mathrm{M}$ for BPI, p15A, and NP-1, respectively). In the presence of sublethal amounts $(500 \mathrm{nM})$ of either p15A or NP1 , as little as $100-200$ pM BPI was sufficient to cause nearly complete bacterial killing in both whole human blood (Fig. $9 \mathrm{~B}$ ) and plasma (not shown), representing a 10-20-fold potentiating

A

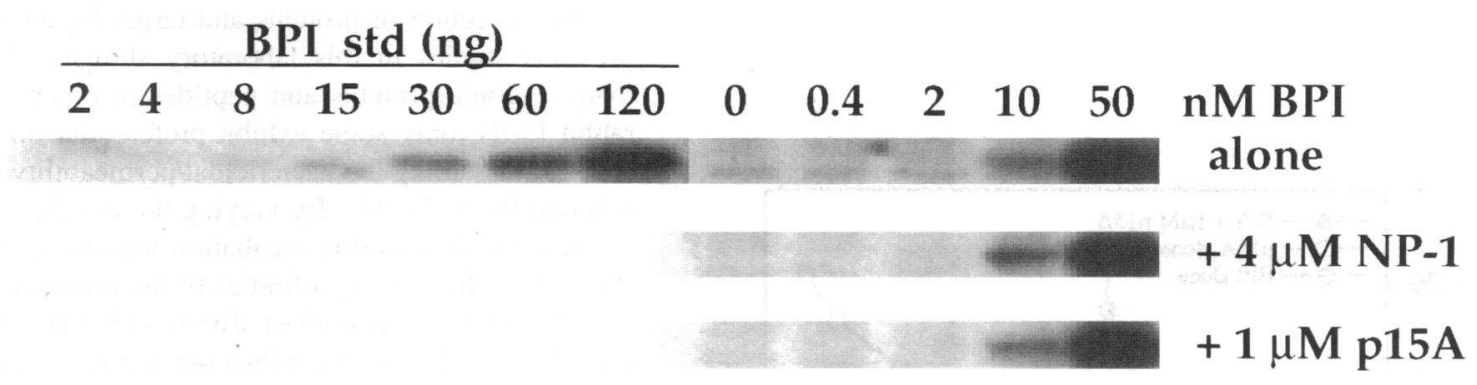

B

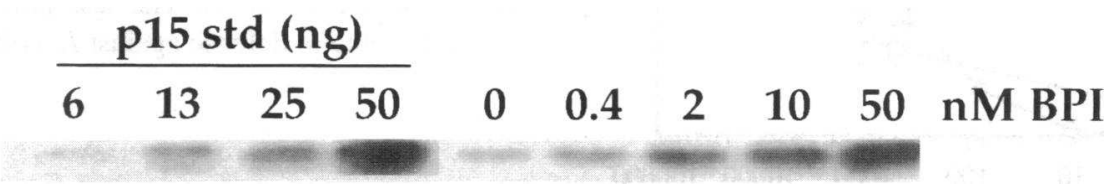

Figure 7. Western blot analysis of BPI and p15 binding to $E$. coli $\mathrm{J} 5$. Bacteria $\left(4 \times 10^{7} / \mathrm{ml}\right)$ prelabeled with $\left[{ }^{14} \mathrm{C}\right]$ oleic acid were incubated in $0.8 \%$ $\mathrm{NB} / \mathrm{saline}, 20 \mathrm{mM}$ sodium phosphate, $\mathrm{pH} 7.4$, with increasing concentrations of BPI $\pm 4 \mu \mathrm{M}$ NP-1 or $1 \mu \mathrm{M}$ p15A for 60 min. Samples were assayed for viability and PL hydrolysis, and the bacteria were centrifuged, washed, and solubilized in SDS-PAGE buffer as described in Methods. ( $A$ ) BPI binding: $10^{7}$ bacteria were loaded per lane of a $12 \%$ polyacrylamide gel for SDS-PAGE and Western analysis. $(B)$ p15A binding: $10^{6}$ bacteria loaded per lane of a $14 \%$ gel. Protein standard curves (std) are indicated. Blotting, immunodetection, and computerized scanning of autoradiograms were performed as described in Methods. 
A
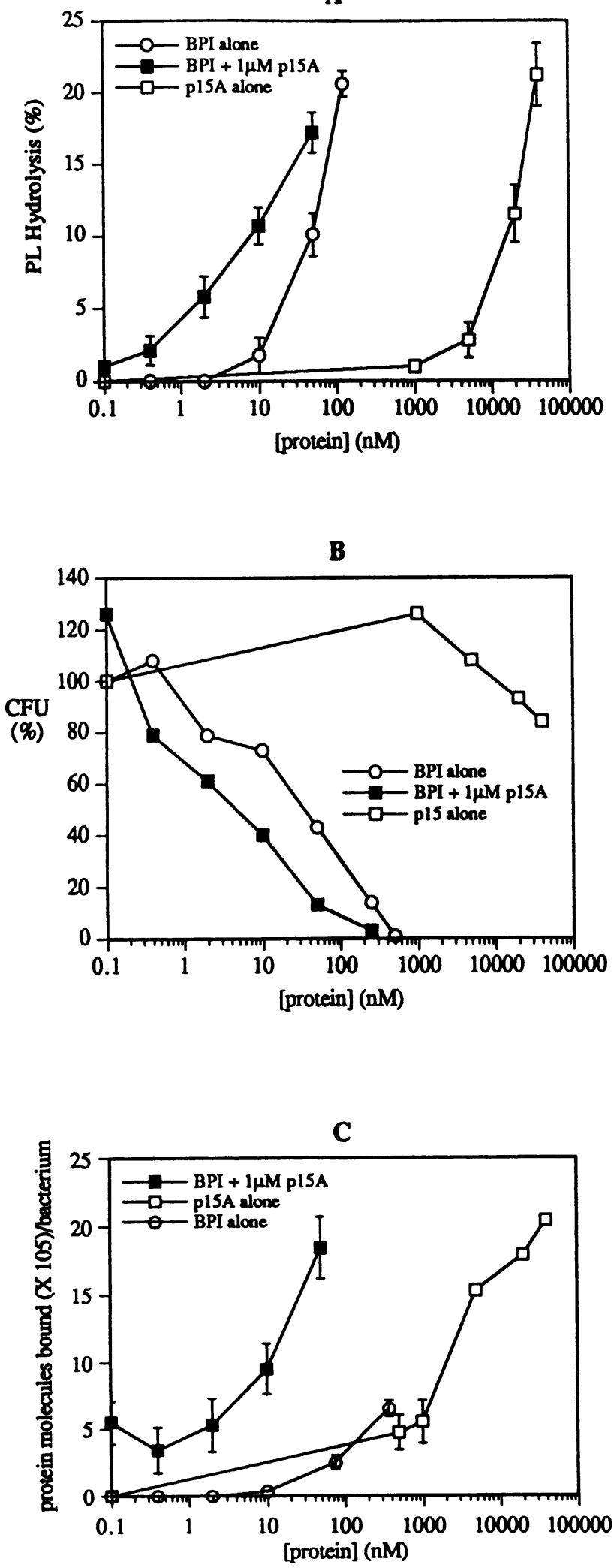

Figure 8. Correlation of antibacterial activities with protein binding. $(A)$ activation of bacterial phospholipid hydrolysis by BPI, p15A, or BPI $+1 \mu \mathrm{M}$ p15A (mean \pm SEM of three to six determinations). (B) Growth inhibition by BPI, p15A, or BPI $+1 \mu \mathrm{M}$ p15A (representative of three effect and thus demonstrating the synergistic action of both p15A and NP-1 with BPI in these settings as well. Similar synergy was observed in rabbit blood (not shown).

$E$. coli $018 \mathrm{~K} 1$ produces long chain (S-chemotype) LPS and is much more resistant to BPI in simple media (not shown) and in whole blood $\left(\mathrm{IC}_{90} 250 \mathrm{nM}\right.$; Fig. $\left.10 \mathrm{~A}\right)$. This organism is also somewhat more resistant to p15A ( IC $\left._{90} \sim 3 \mu \mathrm{M}\right)$ and NP-1 (IC $90>10 \mu \mathrm{M}$ ) in whole blood (Fig. $10 A$ ). At sublethal concentrations, p15A $(2 \mu \mathrm{M})$ or NP-1 $(9 \mu \mathrm{M})$ reduced the BPI dose required to fully inhibit bacterial survival to $\sim 10 \mathrm{nM}$, again representing $a \geq 20$-fold potentiating effect and demonstrating potent synergistic action against this relatively BPI-resistant strain of $E$. coli as well (Fig. $10 \mathrm{~B}$ ).

As observed previously with BPI added in isolation (25), the combined action of BPI plus p15A or NP-1 in blood and plasma results in killing (i.e., no rescue by albumin) of both $E$. coli $\mathrm{K} 1 / \mathrm{r}$ and $018 \mathrm{~K} 1$ (not shown).

\section{Discussion}

Ongoing dissection of the PMN's antimicrobial apparatus has revealed an array of well-defined bioactive proteins and peptides with widely different in vitro potencies and specificities. Why and how the PMN deploys so many antimicrobial agents has been a matter of conjecture. Perhaps this arsenal is redundant, or its complexity merely serves to increase the likelihood that a molecular remedy is present for whatever potential parasite is encountered. Alternatively, these individual antimicrobial agents may be meant to operate sequentially, additively, or synergistically on microbial intruders. We have begun to explore this hypothesis with respect to Gram-negative bacteria by taking advantage of the availability of several purified PMN proteins whose functions in vitro as isolated antimicrobial agents had been well studied and have examined their action alone and in combination against $E$. coli, using both laboratory strains and clinical isolates.

The selection of proteins and target bacteria was based on previous studies in this laboratory showing that, among the many cationic proteins and peptides in crude acid extracts of rabbit PMN, only some exhibit preferential binding to $E$. coli $(13,26)$, including the bactericidal/permeability increasing protein and the p15s (14). By varying the number of bacteria, i.e., the binding sites, during incubation with the extract it could be shown that the binding affinities of the proteins for the bacteria differed. BPI has the highest affinity $(13,14)$. Under conditions that allow binding of the p15s (14), the most cationic members of the rabbit defensins (NP-1 and NP-2) also bind (Fig. 1). The relative affinities of the proteins that can be recovered by elution from the bacteria roughly parallel their antibacterial potencies (BPI $>$ p15A $>$ NP-1). The less potent p15s and defensins may contribute to defense against $E$. coli and related organisms

similar experiments). (C) Binding of BPI alone (open circles), p15A alone (open squares), or of $1 \mu \mathrm{M}$ p15A in the presence of increasing doses of BPI (closed squares). Note: binding of high $(>1 \mu \mathrm{M})$ doses of p15A represent single determinations due to the large amounts of protein required. 

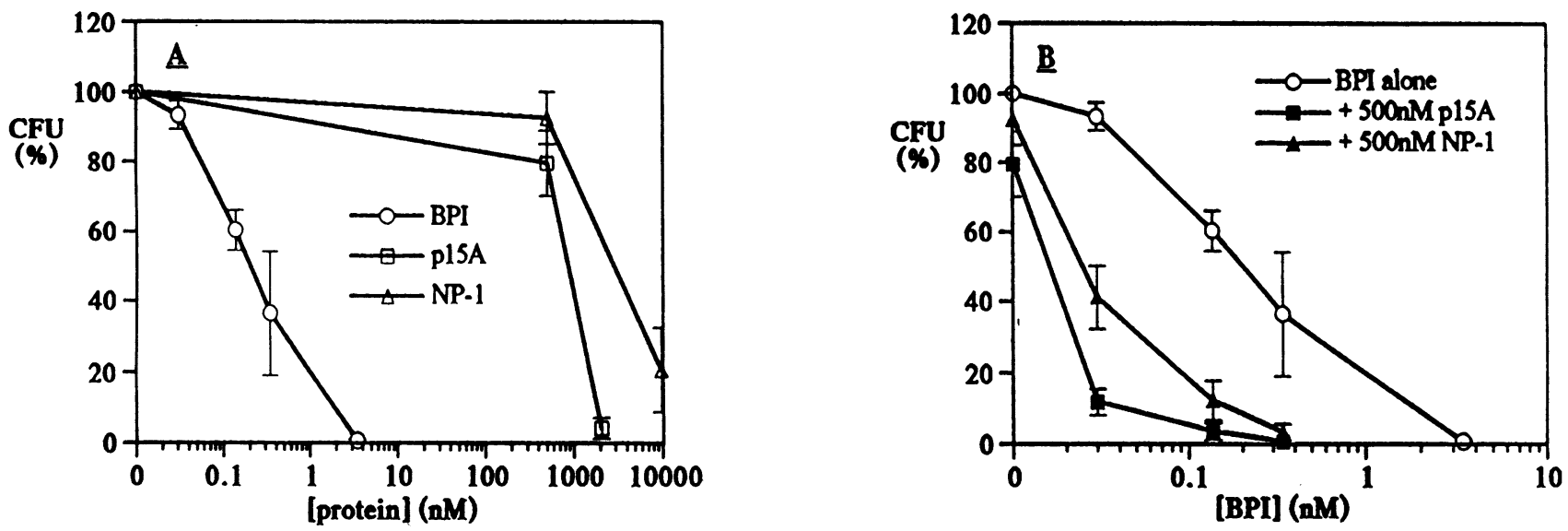

Figure 9. Individual and synergistic actions of granulocyte proteins on $E$. coli $\mathrm{K} 1 / \mathrm{r}$ in whole human blood ex vivo. E. coli $\mathrm{K} 1 / \mathrm{r}\left(10^{4} / \mathrm{ml}\right)$ were incubated in citrated blood at $37^{\circ} \mathrm{C}$ for $1 \mathrm{~h}$ with increasing concentrations of proteins added individually $(A)$ or with BPI $\pm 500 \mathrm{nM}$ p15A or NP-1 $(B)$. The number of viable $E$. coli recovered after incubation in blood is expressed as the percentage of the number of viable $E$. coli initially added to the blood (i.e., percentage of initial innoculum). The results shown represent the mean \pm SEM of three to six determinations.

by their ability to synergize with BPI as well as their relatively higher concentrations in the PMN.

The demonstration in this study of synergy between proteins that share their attraction to the envelope of the target bacterium raises the possibility that a similar approach may be used to identify other antibacterial proteins that may act in concert against other microbial species. However, the striking synergistic effects of BPI and p15A, the more potent of the p15 isoforms that we have isolated (14), and of BPI and NP-1 do not necessarily predict similar cooperativity among other membrane-perturbing antibacterial proteins and peptides. In fact, synergy is not observed when p15A and NP-1 are combined, and the p15s actually inhibit the action of human azurocidin on E. coli (14). Moreover, studies of other antibacterial peptides of insects and amphibians (27) as well as of mammalian (pig) intestine (28) also do not reveal evidence of synergy. On the other hand, lactoferrin at a very high concentration $(2 \mathrm{mg} / \mathrm{ml})$ and lysozyme (29) as well as azurocidin $(100 \mu \mathrm{g} / \mathrm{ml} ; 30)$ or myleoperoxidase (31) and elastase have been shown to act synergistically toward Gram-negative bacteria. However, the potentiating effects were only observed in media of low osmolarity. Activity was blocked by raising the osmolarity above 60 mosM and by physiologic concentrations of either $\mathrm{Ca}^{2+}$ or $\mathrm{Mg}^{2+}$ in the former case (29) or $\mathrm{NaCl}$ exceeding $20 \mathrm{mM}$ in the latter (30). In contrast, the combined effects of $\mathrm{p} 15$ or NP-1 with BPI on $E$. coli are manifest in vitro in simple buffered isotonic media as well as plasma and whole blood, suggesting that these synergistic actions may occur in vivo.

The demonstration of synergy between BPI and p15A or NP-1 suggests that the interaction of these three antimicrobial polypeptides with their target bacteria involves distinct modes of action. We show in this study that the effects on $E$. coli of BPI, p15A, and NP-1 are indeed different. Thus, whereas BPI and $\mathrm{p} 15 \mathrm{~A}$ elicit envelope alterations that promote bacterial
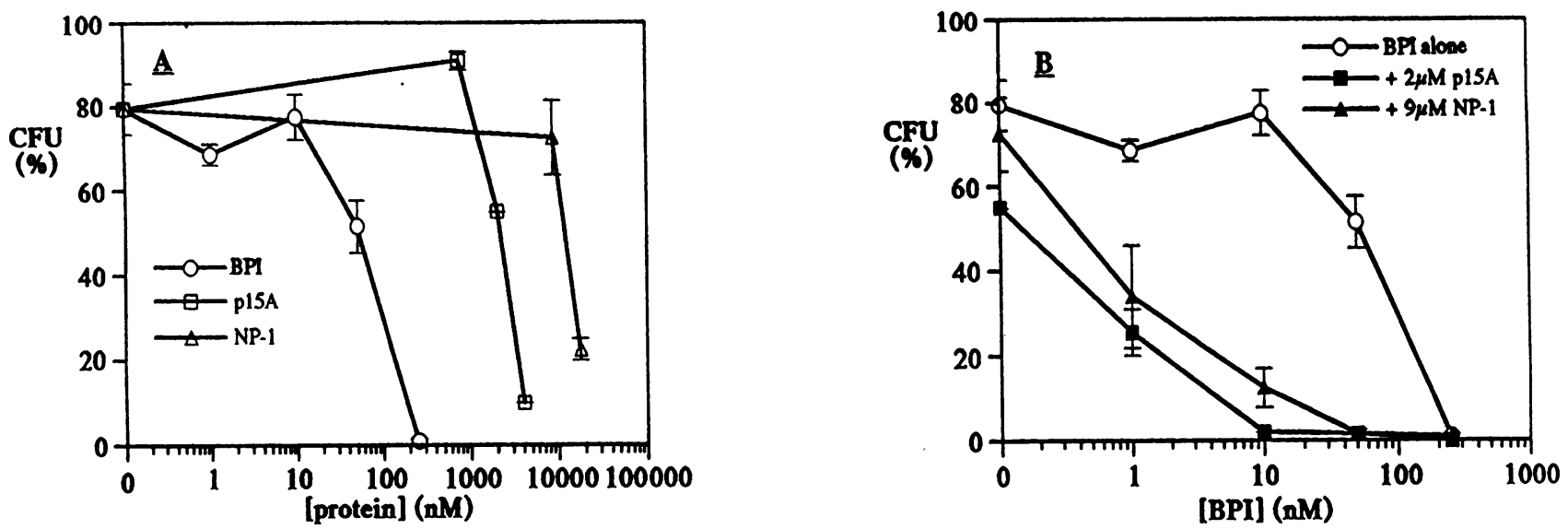

Figure 10. Individual and synergistic actions of granulocyte proteins on $E$. coli $\mathrm{O} 18 \mathrm{~K} 1$ in whole human blood ex vivo. E. coli $\mathrm{O} 18 \mathrm{~K} 1$ were incubated with increasing concentrations of proteins added individually $(A)$ or with BPI $\pm 2 \mu \mathrm{M}$ p15A or $9 \mu \mathrm{M} \mathrm{NP}-1(B)$ under the conditions described in Fig. 9. Results represent the mean \pm SEM of at least two determinations. 


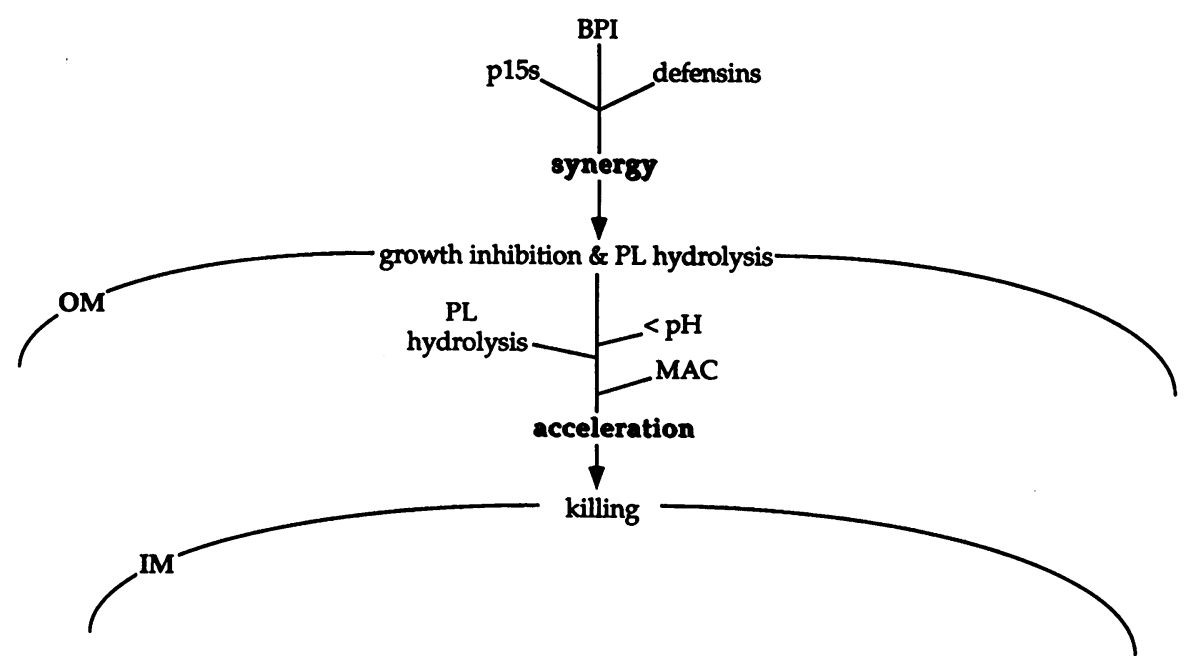

Figure 11. Synergistic action against $E$. coli of BPI and other cellular and extracellular agents. The bacterial outer $(O M)$ and inner (IM) membranes are depicted. MAC denotes the membrane attack complex of complement. phospholipid degradation, NP-1 at very high concentrations does not; although the effects of BPI and p15A on E. coli are qualitatively similar, BPI but not p15A is able to act synergistically with NP-1. Moreover, much more p15A than BPI must be bound to produce the same antibacterial effects, implying that a bound p15 molecule is not equivalent in its cytotoxicity to a bound BPI molecule.

Synergy between two or more agents acting on a given target may result from entirely independent effects or come about via interdependent actions. There are features to the synergy of BPI with p15A or NP-1 that suggest that interdependent actions underly the greater than additive effects. The fact that BPI enhances binding of p15A and that p15A has no effect on BPI binding may argue for potentiation of $\mathrm{p} 15 \mathrm{~A}$ action by BPI. There is a precedent for such a BPI effect: we have shown before that BPI involves another granule-associated PMN protein, a phospholipase $\mathrm{A} 2(32,33)$, in the destruction of target $E$. coli, in part by promoting binding of the enzyme to bacteria (34). On the other hand, the increase in p15A binding per se may be insufficient to account for the increase in antibacterial activity. This is suggested by our observation (unpublished) that human BPI induces the same effects on binding of p15A but synergy is only evident at $\mathrm{pH} 6.0$ and not at $\mathrm{pH}$ 7.4. Therefore, alterations in addition to binding may be necessary before synergy between BPI and p15A becomes manifest.

A more compelling case can be made that the synergy between BPI and NP-1 is attributable to promotion of BPI action by NP-1, because the combined effects of BPI and NP-1 are BPI-like and not NP-1-like. Since the high concentrations of NP-1, relative to BPI, necessary for synergy do not detectably alter the quantity of BPI bound, NP-1 may alter the quality of BPI binding. For example, NP-1 at high concentrations may occupy those sites that BPI binds to when added alone without eliciting detectable bacterial changes. Thus NP-1 may shunt BPI from these "nonproductive" sites either to the same but altered or to biochemically or topologically distinct sites that have greater affinity for BPI than for NP-1 and that more directly lead to antibacterial effects. We wish to consider the possibility that such a scheme might also explain the synergy induced by $\mathrm{p} 15 \mathrm{~A}$ and thus explain the striking similarities in the synergistic actions of NP-1 and p15A with BPI (see Figs. $3,6,9$, and 10) despite the differences in their independent actions. The further analysis of these concepts falls beyond the scope of this study.

The antibacterial action of BPI against $E$. coli occurs in two stages. First, there are almost instantaneous alterations in the bacterial outer envelope (including activation of bacterial phospholipid hydrolysis) accompanied by a potentially reversible growth arrest, followed by a slow progression to lethal injury linked to effects on the inner membrane (11). Our data show that the synergistic effects of the p15s or defensins with BPI are limited to the early phase of antibacterial events: defensins do not accelerate bacterial killing by BPI (i.e., it remains albumin-reversible at early times; Fig. 5), and, as we have shown before, p15s actually retard the progression to later lethal effects (14). In contrast, late components of complement act synergistically with BPI, both in the presence and absence of $\mathrm{p} 15 \mathrm{~A}$ or NP-1, to accelerate the progression from sublethal to lethal effects $(11,25)$. The transition from the bacteriostatic to the bactericidal effect of BPI on $E$. coli is also accelerated by lower $\mathrm{pH}$ and by conditions that promote action of bacterial and host phospholipases on bacterial phospholipids in the inner membrane $(11,32$, 33). Thus, BPI functions in a complex environment where both intracellular and extracellular host factors can combine with BPI to enhance antibacterial action (Fig. 11).

In conclusion, the granule-associated proteins that we have studied act synergistically in vitro. Their joint delivery either into the phagosome or extracellularly during degranulation may also optimize microbicidal events in vivo, especially against large numbers of bacteria or strains that are more resistant to serum and phagocytosis. Moreover, the activity in vitro of the three antibacterial proteins in physiologic extracellular fluids, including whole blood and undiluted plasma, should be viewed vis-à-vis abundant evidence of extracellular release of granuleassociated PMN proteins both in inflammatory sites and also in the circulation during serious infections (35-37). It has been reported that PMN treated with FMLP and cytochalasin in vitro secrete large portions of their BPI content (38). We have observed, under more physiologic conditions, the gradual accumu- 
lation of substantial concentrations of BPI $(\sim 1 \mu \mathrm{g} / \mathrm{ml}$ or 20 $\mathrm{nM})$ and $\mathrm{p} 15 \mathrm{~s}(\sim 15 \mu \mathrm{g} / \mathrm{ml}$ or $1 \mu \mathrm{M})$ in the extracellular (ascitic) fluid of glycogen-induced inflammatory rabbit peritoneal exudates at molar ratios similar to those required for synergy in vitro (Weinrauch Y., et al., manuscript in preparation). Moreover, a recent clinical study (39) revealed that the mean normal concentration of defensins (42 ng/ml, $\sim 12 \mathrm{nM})$ in human plasma increased dramatically during sepsis, ranging from 900 $\mathrm{ng} / \mathrm{ml}$ to $180 \mu \mathrm{g} / \mathrm{ml}(250 \mathrm{nM}$ to $50 \mu \mathrm{M})$. Thus, the appearance during inflammation of these antimicrobial proteins in body fluids may serve to extend their bioactive range from the phagosome to the extracellular environment where they can also act in synergy.

Recombinant BPI has been tested as a therapeutic agent against Gram-negative bacterial infections and endotoxemia (40). The ability of proteins such as p15A and the more cationic defensins to act synergistically with BPI suggests that they may be used as pharmacologic adjuncts.

This study sets the stage for the further exploration of synergy among antibacterial proteins and peptides, including possible interactions between oxidative and oxygen-independent antimicrobial systems. Accordingly, we have initiated examination of human PMN for homologues of $\mathrm{p} 15 \mathrm{~s}$ or defensins or other agents capable of acting synergistically with human BPI.

\section{Acknowledgments}

We thank Drs. Constance Capodici, Chen Shu, and Yvette Weinrauch as well as Sylvia S. L. Harwig, Seth Katz, Lisa Madsen, and Kol Zarember for excellent technical advice and assistance.

This work was supported by U.S. Public Health Service grants R37DK05472 and AI18571. Ofer Levy is supported by a National Institutes of Health Training Grant 5T32GM07308 from the National Institute of General Medical Science. Protein sequencing was performed at the UCLA Protein Microsequencing Facility, supported by a Biomedical Research Support Shared Instrumentation Grant (1S10RR0554) from the National Institutes of Health.

\section{References}

1. Klebanoff, S. J. 1992. Oxygen metabolites from phagocytes. In Inflammation: Basic Principles and Clinical Correlates. J. I. Gallin, I. M. Goldstein, and R. Snyderman, editors. Raven Press, New .York. 541-588.

2. Elsbach, P., and J. Weiss. 1992. Oxygen-independent antimicrobial systems of phagocytes. In Inflammation: Basic Principles and Clinical Correlates. J. I. Gallin, I. M. Goldstein, and R. Snyderman, editors. Raven Press, New York.

3. Heyworth, P. G., P. Peveri, and J. Curnutte. 1992. Cytosolic components of NADPH oxidase: identity, function, and role in regulation of oxidase activity. In Cellular and Molecular Mechanisms of Inflammation, Vol. 4, Biological Oxidants. C. G. Cochrane and M. A. Gimbrone, Jr., editors. Academic Press Inc., New York. 43-81.

4. Lehrer, R. I., and T. Ganz. 1990. Antimicrobial polypeptides of human neutrophils. Blood. 76:2169-2181.

5. Gabay, J. E., R. W. Scott, D. Campanelli, J. Griffith, C. Wilde, M. N. Marra, M. Seeger, and C. F. Nathan. 1989. Antibiotic proteins of human polymorphonuclear leukocytes. Proc. Natl. Acad. Sci. USA. 86:5610-5614.

6. Gabay, J. E., and R. P. Almeida. 1993. Antibiotic peptides and serine protease homologs in human polymorphonuclear leukocytes: defensins and azurocidin. Curr. Opin. Immunol. 5:97-102.

7. Gennaro, R., D. Romeo, B. Skerlavaj, and M. Zanetti. 1991. Neutrophil and eosinophil granules as stores of defense proteins. In Blood Cell Biochemistry, vol. 3. J. R. Harris, editor. Plenum Publishing Corp., New York. 335-368.

8. Elsbach, P., and J. Weiss. 1993. Bactericidal/permeability-increasing protein and host defense against Gram-negative bacteria and endotoxin. Curr. Opin. Immunol. 5:103-107.

9. Elsbach, P., and J. Weiss. 1993. The bactericidal/permeability-increasing protein (BPI), a potent element in host-defense against Gram-negative bacteria and lipopolysaccharide. Immunobiology. 187:417-429.

10. Lehrer, R. I., A. K. Lichtenstein, and T. Ganz. 1993. Defensins: antimicrobial and cytotoxic peptides of mammalian cells. Annu. Rev. Immunol. 11:105128.

11. Mannion, B. A., J. Weiss, and P. Elsbach. 1990. Separation of sublethal and lethal effects of the bactericidal/permeability-increasing protein on Escherichia coli. J. Clin. Invest. 85:853-860.

12. Mannion, B. A., J. Weiss, and P. Elsbach. 1990. Separation of sublethal and lethal effects of polymorphonuclear leukocytes on Escherichia coli. J. Clin. Invest. 86:631-641.

13. Mannion, B. A., E. S. Kalatzis, J. Weiss, and P. Elsbach. 1989. Preferential binding of the neutrophil cytoplasmic granule-derived bactericidal/permeabilityincreasing protein to target bacteria. J. Immunol. 142:2807-2812.

14. Ooi, C. E., J. Weiss, O. Levy, and P. Elsbach. 1990. Isolation of two isoforms of a novel $15 \mathrm{kDa}$ protein from rabbit polymorphonuclear leukocytes that modulate the antibacterial actions of other leukocyte proteins. J. Biol. Chem. 265:15956-15962.

15. Levy, O., J. Weiss, K. Zarember, C. E. Ooi, and P. Elsbach. 1993. Antibacterial 15-kDa protein isoforms (p15s) are members of a novel family of leukocyte proteins. J. Biol. Chem. 268:6058-6063.

16. Weiss, J., M. Victor, A. S. Cross, and P. Elsbach. 1982. Sensitivity of K1-encapsulated Escherichia coli to killing by the bactericidal/permeability-increasing protein of rabbit and human neutrophils. Infect. Immun. 38:1149-1153.

17. Selsted, M. E., S. S. L. Harwig, T. Ganz, J. W. Schilling, and R. I. Lehrer. 1985. Primary structures of three human neutrophil defensins. J. Clin. Invest. 76:1436-1439.

18. Lehrer, R. I., M. Rosenmann, S. S. L. Harwig, R. Jackson, and P. Eisenhauer. 1991. Ultrasensitive assays for endogenous antimicrobial polypeptides. $J$. Immunol. Methods. 137:167-173.

19. Selsted, M. E., D. Szklarek, and R. I. Lehrer. 1984. Purification and antibacterial activity of antimicrobial peptides of rabbit granulocytes. Infect. Immun. 45:150-154.

20. Sambrook, J., E. F. Fritsch, and T. Maniatis. 1989. Molecular Cloning: A Laboratory Manual. Cold Spring Harbor Laboratory, Cold Spring Harbor, NY. Vol III, p.B.25.

21. Sambrook, J., E. F. Fritsch, and T. Maniatis. 1989. Molecular Cloning: A Laboratory Manual. Cold Spring Harbor Laboratory, Cold Spring Harbor, NY. Vol III, p.B.18.6.

22. Selsted, M. E., D. M. Brown, R. J. DeLange, and R. I. Lehrer. 1983 Primary structures of MCP-1 and MCP-2, natural peptide antibiotics of rabbit lung macrophages. J. Biol. Chem. 258:14495-14489.

23. Berenbaum, M. C. 1989. What is synergy? Pharmacol. Rev. 41:93-141.

24. Elsbach, P., J. Weiss, R. C. Franson, S. Beckerdite-Quagliata, A. Schneider, and L. Harris. 1979. Separation and purification of a potent bactericidal/ permeability-increasing protein and a closely associated phospholipase A2 from rabbit polymorphonuclear leukocytes. J. Biol. Chem. 254:11000-11009.

25. Weiss, J., P. Elsbach, C. Shu, J. Castillo, L. Grinna, A. Horwitz, and G. Theofan. 1992. Human bactericidal/permeability-increasing protein and a recombinant $\mathrm{NH}_{2}$-terminal fragment cause killing of serum-resistant Gram-negative bacteria in whole blood and inhibit tumor necrosis factor release induced by the bacteria. J. Clin. Invest. 90:1122-1130.

26. Litteri, L., and D. Romeo. 1993. Characterization of bovine neutrophil antibacterial polypeptides which bind to Escherichia coli. Infect. Immun. 61:966969.

27. Casteels, P., C. Ampe, F. Jacobs, and P. Tempst. 1993. Functional and chemical characterization of Hymenoptaecin, an antibacterial polypeptide that is infection-inducible in the honeybee (Apis mellifera). J. Biol. Chem. 268:70447054.

28. Boman, H. G., B. Agerberth, and A. Boman. 1993. Mechanisms of action on Escherichia coli of Cecropin P1 and PR-39, two antibacterial peptides from pig intestine. Infect. Immun. 61:2978-2984.

29. Ellison, R. T., III, and T. J. Giehl. 1991. Killing of Gram-negative bacteria by lactoferrin and lysozyme. J. Clin. Invest. 88:1080-1091.

30. Miyasaki, K. T., and A. L. Bodeau. 1992. Human neutrophil azurocidin synergizes with leukocyte elastase and Cathepsin G in the killing of Capnocytophaga sputigena. Infect. Immun. 60:4973-4975.

31. Odeberg, H., and I. Olsson. 1976. Microbicidal mechanisms of human granulocytes: synergistic effects of granulocyte elastase and myeloperoxidase or chymotrypsin-like cationic proteins. Infect. Immun. 14:1276-1283.

32. Wright, G. C., J. Weiss, K. S. Kim, H. Verheij, and P. Elsbach. 1990. Bacterial phospholipid hydrolysis enhances the destruction of Escherichia coli ingested by rabbit neutrophils. J. Clin. Invest. 85:1925-1935.

33. Wright, G. C., C. E. Ooi, J. Weiss, and P. Elsbach. 1990. Purification of a cellular (granulocyte) and an extracellular (serum) phospholipase A2 that 
participates in the destruction of Escherichia coli in a rabbit inflammatory exudate. J. Biol. Chem. 265:6675-6681.

34. Forst, S., J. Weiss, J. M. Maragonore, R. L. Heinrikson, and P. Elsbach. 1987. Relation between binding and the action of phospholipases $A_{2}$ on Escherichia coli exposed to the bactericidal/permeability-increasing protein of neutrophils. Biochim. Biophys. Acta. 920:221-225.

35. Jansen, N. J. G., W. V. Oeveren, B. H. Hoiting, and C. H. R. H. Wildevuur 1991. Activation of plasma systems and blood cells by endotoxin in rabbits. Inflammation. 15:81-90.

36. Nakamura, H., K. Yoshimura, N. G. McElvaney, and R. G. Crystal. 1992 Neutrophil elastase in respiratory epithelial lining fluid of individuals with cystic fibrosis induces interleukin-8 gene expression in a human bronchial epithelial cell line. J. Clin. Invest. 89:1478-1484.
37. Hoffman, J. A., C. Hetru, and J. M. Reichhart. 1993. The humoral antibacterial response of Drosophila. FEBS (Fed. Eur. Biochem. Soc.) Lett. 325: 63-66.

38. Marra, M. N., C. G. Wilde, M. S. Collins, J. L. Snable, M. B. Thornton, and R. W. Scott. 1992. The role of bactericidal/permeability-increasing protein as a natural inhibitor of bacterial endotoxin. J. Immunol. 148:532-537.

39. Panyutich, A. V., E. A. Panyutich, V. A. Krapivin, E. A. Baturevich, and T. Ganz. 1993. Plasma defensin concentrations are elevated in patients with septicemia or bacterial meningitis. J. Lab. Clin. Med. 122:202-207.

40. Kohn, F. R., W. S. Ammons, A. Horwitz, L. Grinna, G. Theofan, J. Weickmann, and A. H. C. Kung. 1993. Protective effect of a recombinant amino terminal fragment of bactericidal/permeability-increasing protein in experimental endotoxemia. J. Infect. Dis. 168:1307-1310. 